\title{
Protocol
}

\section{Noninvasive Human Nuclear Transfer with Embryonic Stem Cells}

\author{
Sohyun L. McElroy ${ }^{1}$ and Renee A. Reijo Pera \\ Center for Human Embryonic Stem Cell Research and Education, Institute for Stem Cell Biology and Regenerative Medicine, \\ Department of Obstetrics and Gynecology, Stanford University, Palo Alto, CA 94304-5542, USA
}

\section{INTRODUCTION}

In somatic cell nuclear transfer (SCNT), the nucleus of a somatic cell is transferred to an enucleated oocyte for reprogramming to an embryonic cell state through the use of the endogenous machinery. SCNT technology has been used to produce offspring, establish embryonic stem cells, and study epigenetic reprogramming, as mediated by oocytes, in several animal species. In humans, there are ethical and practical issues that limit availability of oocytes donated by women of reproductive age specifically for research. Thus, there is a need to more exhaustively explore alternatives, including oocyte sources and different SCNT protocols. Nuclear transfer (NT) techniques are important factors that impact development of NT embryos. The procedures of enucleation of oocyte genetic material and introduction of the donor nucleus vary depending on species and laboratories. Hoechst staining has been used successfully for invasive enucleation in many animal studies, though it is known that Hoechst staining and ultraviolet (UV) light can damage oocyte mitochondrial DNA. More recently, noninvasive NT techniques that rely on polarized microscopic imaging systems have been used to visualize the meiotic spindle without DNA staining and UV illumination. This protocol describes a method for noninvasive human nuclear transfer by visualizing the oocyte spindle without DNA staining.

\section{RELATED INFORMATION}

Alternative human oocyte sources are discussed by McElroy et al. (2008). A protocol for Culturing Human Embryonic Stem Cells in Feeder-Free Conditions (McElroy and Reijo Pera 2008) is also available.

\section{MATERIALS}

CAUTIONS AND RECIPES: Please see Appendices for appropriate handling of materials marked with $<!>$, and recipes for reagents marked with $<R>$.

\section{Reagents}

Calcium ionophore $(10 \mu \mathrm{M})$ (Sigma-Aldrich)

Culture media (Cooper Surgical)

Use HEPES media to wash oocytes whenever media are changed, for example between cytochalasin B and cleavage medium (Steps 9 and 10), and between cleavage medium and HEPES working drop (Steps 10 and 11).

Quinn's Advantage medium with HEPES $\left(\mathrm{Ca}^{2+} / \mathrm{Mg}^{2+}\right.$-free)

Quinn's Advantage medium with HEPES

Quinn's Advantage Serum Protein Substitute (SPS) 
Quinn's Advantage Cleavage medium

Quinn's Advantage Blastocyst medium

$<$ ! Cytochalasin B $(7.5 \mu \mathrm{g} / \mathrm{mL})$ (Sigma-Aldrich)

$<$ !>DMAP (2 mM) (4-dimethylaminopyridine; Sigma-Aldrich)

Human embryonic stem cells (hESCs), cultured as described in Culturing Human Embryonic

Stem Cells in Feeder-Free Conditions (McElroy and Reijo Pera 2008)

Human oocytes

In vitro matured or failed-fertilized oocytes can be used for this purpose as previously described (Lavoir et al. 2005; Stojkovic et al. 2005; Heindryckx et al. 2007).

$<$ R $>$ Mannitol fusion medium

Mineral oil (Cooper Surgical)

Phosphate-buffered saline (PBS) (Sigma-Aldrich)

Phosphate-buffered saline (PBS) containing $5 \%(\mathrm{v} / \mathrm{v})$ fetal bovine serum (FBS)

TrypLE Express (Gibco)

\section{Equipment}

Aspirator tube (Sigma-Aldrich)

Bunsen burner

Capillary tubes (glass; Fisher Scientific)

Centrifuge

Dish (glass-bottom, 50-mm diameter [40-mm diameter glass]) (Intracel)

Electro-cell manipulator (ECM 2001) (BTX)

Fusion chamber with 3.2-mm gap (BTX)

Incubator (humidified, $37^{\circ} \mathrm{C}, 5 \% \mathrm{CO}_{2}$ )

Incubator (humidified, $37^{\circ} \mathrm{C}, 6 \% \mathrm{CO}_{2}, 5 \% \mathrm{O}_{2^{\prime}}$ and $89 \% \mathrm{~N}_{2}$ )

Micromanipulators (Eppendorf)

Microscope (differential interference contrast [DIC]; Leica; with thermo plate inserted at the objective stage

Microscope (stereo dissecting; Leica)

Oosight Imaging System (Cambridge Research \& Instrumentation Inc.)

Petri dishes (35-mm and 60-mm) (Falcon)

Pipette (holding, 25- $\mu \mathrm{m}$ inner diameter, 120- to 150- $\mu \mathrm{m}$ outer diameter) (Humagen Fertility Diagnostics)

Pipette (beveled, 13- to 15- $\mu \mathrm{m}$ inner diameter) (Humagen Fertility Diagnostics)

Plates (tissue culture, 12-well)

Syringe (1-mL) (Fisher Scientific)

Thermo plate (MATS)

\section{METHOD}

\section{Experiment Set-Up}

1. Prepare culture media (two dishes of cleavage medium with $10 \%$ SPS, and one dish of $2 \mathrm{mM}$ DMAP):

i. Place $10-15$ drops of medium ( $20 \mu \mathrm{L}$ per drop) in a $35-\mathrm{mm}$ Petri dish.

ii. Cover with $3.5-5 \mathrm{~mL}$ of mineral oil.

iii. Pre-equilibrate all culture media at $37^{\circ} \mathrm{C}$ in $6 \% \mathrm{CO}_{2^{\prime}} 5 \% \mathrm{O}_{2^{\prime}}$ and $89 \% \mathrm{~N}_{2}$ for at least $4 \mathrm{~h}$ or overnight before use.

2. Turn on the microscope and thermo plate to prewarm.

3. Prepare one $60-\mathrm{mm}$ Petri dish containing $15-20$ drops (20 $\mu \mathrm{L}$ per drop) of medium with HEPES $\left(\mathrm{Ca}^{2+} / \mathrm{Mg}^{2+}\right.$-free) containing 5\% SPS, one 30-mm Petri dish containing 15-20 drops (20 $\mu \mathrm{L} \mathrm{per}$ 
drop) of $7.5 \mu \mathrm{g} / \mathrm{mL}$ cytochalasin B, and one glass-bottom dish containing 3-4 drops (4 $\mu \mathrm{L}$ per drop) of HEPES containing $5 \%$ SPS. Prewarm the dishes at $37^{\circ} \mathrm{C}$ on a thermo plate.

4. Attach the holding and beveled pipettes into micromanipulators. Avoid any air bubbles in the manipulator tubes to ensure smooth movement of the manipulators.

5. Prepare a capillary tube for use in transferring oocytes:

i. Heat a glass capillary tube at a point one-third of the distance from one end, using a Bunsen burner. Pull the tube from both the left and right sides to detach the end.

ii. Cut off the end segment either by using a diamond cutter or by rubbing with another capillary tube on the edge of a 10-cm Petri dish.

iii. Flame the end of the capillary tube and assemble into an aspirator tube and 1-mL syringe. Alternatively, commercially available embryo transfer equipment (Stripper and tips; MidAtlantic Diagnostics) can be used to transfer oocytes.

\section{Donor Human Embryonic Stem Cell Preparation}

6. Culture donor hESCs in feeder-free conditions in 12-well plates in $5 \% \mathrm{CO}_{2}$, as described in Culturing Human Embryonic Stem Cells in Feeder-Free Conditions (McElroy and Reijo Pera 2008).

7. Wash hESCs once with PBS. Add $0.5 \mathrm{~mL}$ of TrypLE Express, and incubate for $5 \mathrm{~min}$ at $37^{\circ} \mathrm{C}$ to dissociate the donor cells.

8. Suspend hESCs in $4.5 \mathrm{~mL}$ of PBS with $5 \%$ FBS, and centrifuge at $200 \mathrm{~g}$ for $5 \mathrm{~min}$. Aspirate supernatant and resuspend single cells in PBS containing 5\% FBS by vigorous pipetting.

\section{Nuclear Transfer}

9. Incubate oocytes in the prewarmed cytochalasin B for $5-15$ min at $37^{\circ} \mathrm{C}$ on a warm plate.

10. Visualize the meiotic spindle, based on its high birefringence, in the Oosight Imaging System as described by Liu et al. (2000). Insert a beveled pipette through the zona pellucida (ZP) and aspirate the meiotic spindle into the pipette as shown in Figure 1. Incubate the enucleated oocyte in cleavage medium for $30 \mathrm{~min}$ at $37^{\circ} \mathrm{C}$ in $5 \% \mathrm{CO}_{2}$ in humidified air.

11. Using gentle pressure, inject a single donor cell into the oocyte perivitelline space in HEPES drops on the glass-bottom dish. Perform the injection under the inverted microscope to make sure that a single cell is injected. Fuse the donor cell with the oocyte complex in mannitol fusion medium by applying two consecutive electrofusion pulses of $1.8 \mathrm{~V} / \mathrm{cm}$ of $15-\mu \mathrm{sec}$ duration, using an electro-cell manipulator.

12. Incubate nuclear-transferred oocytes in cleavage medium for $2 \mathrm{~h}$ at $37^{\circ} \mathrm{C}$ in a humidified incubator.

13. Check the fusion rate under the stereomicroscope by confirming the absence of the donor cell in the perivitelline space.

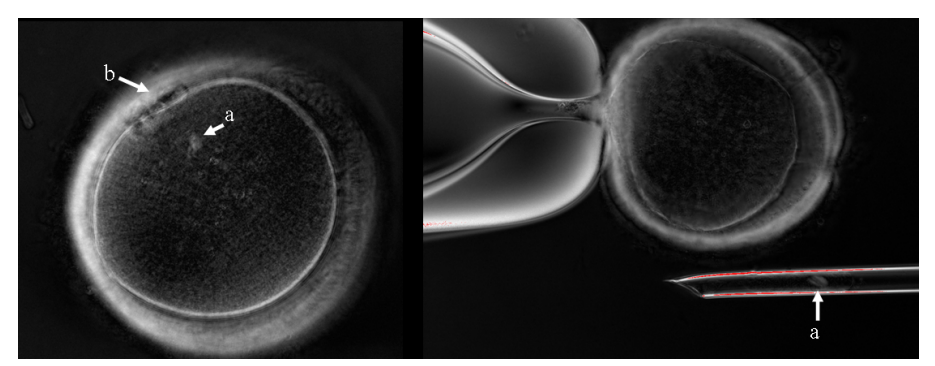

FIGURE 1. (Left) Meiotic spindle view of mature oocyte under the Oosight Imaging System; (a) meiotic spindle, (b) first polar body. (Right) The enucleated oocyte and karyoplast containing the meiotic spindle in the pipette; (a) pipette. 
Check the fusion rate $30 \mathrm{~min}$ after fusion. If the donor cell is not fused with the oocyte, repeat the fusion protocol described in Step 11 with the oocyte and donor cell complex.

14. Activate fused NT oocytes using $10 \mu \mathrm{M}$ calcium ionophore for $5 \mathrm{~min}$ in a dark room, followed by incubation in $2 \mathrm{mM}$ DMAP for $4 \mathrm{~h}$ at $37^{\circ} \mathrm{C}$ in $5 \% \mathrm{CO}_{2}$ in humidified air.

15. Prepare cleavage medium with $10 \%$ SPS and blastocyst medium with $10 \%$ SPS. Culture NT embryos in a biphasic culture (cleavage medium with 10\% SPS for the first $3 \mathrm{~d}$, and blastocyst medium with $10 \%$ SPS for the second $2-3 \mathrm{~d}$ ) at $37^{\circ} \mathrm{C}$ in $6 \% \mathrm{CO}_{2}, 5 \% \mathrm{O}_{2}$, and $89 \% \mathrm{~N}_{2}$. Pronuclear formation of NT embryos can be observed 16-18 h post-activation. Monitor embryo development every day under the microscope.

\section{REFERENCES}

Heindryckx, B., De Sutter, P., Gerris, J., Dhont, M., and Van der Elst, J. 2007. Embryo development after successful somatic cell nuclear transfer to in vitro matured human germinal vesicle oocytes. Hum. Reprod. 22: 1982-1990.

Lavoir, M.C., Weier, J., Conaghan, J., and Pedersen, R.A. 2005. Poor development of human nuclear transfer embryos using failed fertilized oocytes. Repro. Biomed. Online. 11: 740-744.

Liu, L., Oldenbourg, R., Trimarchi, J.R., and Keefe, D.L. 2000. A reliable, noninvasive technique for spindle imaging and enucleation of mammalian oocytes. Nature Biotechnol. 18: 223-225.

McElroy, S.L. and Reijo Pera, R.A. 2008. Culturing human embryonic stem cells in feeder-free conditions. CSH Protocols (this issue). doi: $10.1101 /$ pdb.prot5044.

McElroy, S.L., Kee, K., Tran, N., Meneses, J., Giudice, L.C., and Reijo Pera, R.A. 2008. Developmental competence of immature and failed/abnormally fertilized human oocytes in nuclear transfer. Reprod. BioMed. Online 16: 684-693.

Stojkovic, M., Stojkovic, P., Leary, C., Hall, V.J., Armstrong, L., Herbert, M., Nesbitt, M., Lako, M., and Murdoch, A. 2005. Derivation of a human blastocyst after heterologous nuclear transfer to donated oocytes. Reprod. Biomed. Online. 11: 226231. 


\title{
Noninvasive Human Nuclear Transfer with Embryonic Stem Cells
}

\author{
Sohyun L. McElroy and Renee A. Reijo Pera
}

Cold Spring Harb Protoc; doi: 10.1101/pdb.prot5040

\begin{tabular}{|c|c|}
\hline $\begin{array}{l}\text { Email Alerting } \\
\text { Service }\end{array}$ & Receive free email alerts when new articles cite this article - click here. \\
\hline $\begin{array}{l}\text { Subject } \\
\text { Categories }\end{array}$ & $\begin{array}{l}\text { Browse articles on similar topics from Cold Spring Harbor Protocols. } \\
\text { Cell Biology, general (1382 articles) } \\
\text { Cell Culture (301 articles) } \\
\text { Developmental Biology (728 articles) } \\
\text { DNA Delivery/Gene Transfer ( } 344 \text { articles) } \\
\text { DNA Delivery/Gene Transfer, general (341 articles) } \\
\text { Embryonic Stem Cells (55 articles) } \\
\text { Non-Viral Methods (226 articles) } \\
\text { Stem Cells ( } 46 \text { articles) } \\
\text { Stem Cells, general (70 articles) } \\
\text { Transgenic Technology, general (187 articles) } \\
\text { Transgenics, Other Organisms (34 articles) }\end{array}$ \\
\hline
\end{tabular}

